\section{Marketing Strategies Used by U.S. Landscape Services Firms}

\author{
Alicia L. Rihn \\ Department of Agricultural and Resource Economics, University of Tennessee, \\ 321C Morgan Hall, 2621 Morgan Circle Drive, Knoxville, TN 37996-4500
}

Ariana Torres

Department of Horticulture and Landscape Architecture and Agricultural Economics, Purdue University, 625 Agriculture Mall Drive, West Lafayette, IN 47907

\section{Susan S. Barton}

Department of Plant and Soil Sciences, University of Delaware, 146 Townsend Hall, Newark, DE 19716

\section{Bridget K. Behe \\ Department of Horticulture, Michigan State University, 1066 Bogue Street, East Lansing, MI 48824}

\section{Hayk Khachatryan \\ Food and Resource Economics Department, University of Florida, Mid- Florida Research and Education Center, 2725 S. Binion Road, Apopka, FL 32779}

Additional index words. advertising, pricing strategy, retailer, wholesale grower

\begin{abstract}
The landscape service sector is an important part of the environmental horticulture industry. However, research addressing factors impacting its business and marketing practices are scarce. This manuscript uses data collected via online and mail industry surveys in 2014 and 2019 to investigate U.S. landscape service firms' advertising and marketing practices and different factors that influence their business strategies by firm type and size. Product mix, advertising method, and the importance of different business factors were impacted by firm type. Landscape service only firms had the most diverse product offerings, while firms with wholesale production had the least diversity. Landscape service only firms primarily used in-person and telephone advertising, while firms with wholesale production used a broader swath of advertising medias to reach a more diversified clientele. Overall, weather and laborrelated factors had the most impact on landscaping firms' business practices. Larger firms perceived labor factors as more important than smaller firms.
\end{abstract}

The landscaping design and services industry is the leading economic contributor within the U.S. environmental horticulture industry, with estimated contributions reaching 1.5 million (M) jobs, $\$ 221.89$ billion (B) in sales revenue, \$79.6 B labor income, \$119.1 $\mathrm{B}$ value added, and $\$ 24.7 \mathrm{~B}$ state and federal taxes in 2018 (Hall et al., 2020). The U.S. environmental horticulture industry, broadly defined as the green industry, is comprised of service providers (e.g., landscape design, installation, and maintenance firms) as well as production firms (e.g., wholesale nursery, greenhouse, and turfgrass sod producers), and wholesale and retail distribution firms such as garden centers, home stores, mass merchandisers with lawn/garden departments, brokers and re-wholesale distribution centers, and allied trades suppliers of inputs to the industry. Much like the other sectors of the green industry, firms in the landscaping services industry engage in marketing practices to influence elasticity of demand and potentially affect profits favorably. However, research literature investigating the relationship between advertising efforts, marketing strategies, and factors impacting other business decisions (for example prices or geographical expansion) is limited.

Although lacking in the landscape services sector of the green industry, marketing and business practices have been addressed in other sectors, such as nursery and greenhouse operations (Behe et al., 2008; Campbell and Hall, 2010; Li et al., 2019; Palma et al., 2012). Many different factors influence business decisions in the green industry as a whole (Campbell and Hall, 2010). For instance, Palma et al. (2012) investigated the return-on-investment for advertising by green industry firms. Returns varied by firm size and media type, but internet advertisements generated an estimated average return of $\$ 5.9$ per dollar spent on advertising for small firms $(\$ 10 \mathrm{~K}-\$ 250 \mathrm{~K}$ sales) and $\$ 7.5$ returns per dollar spent on advertising for medium-sized firms ( $\$ 250 \mathrm{~K}-\$ 1 \mathrm{M}$ sales). Relatedly, Li et al. (2019) determined that firm size impacted the relationship between advertising expenditures and annual gross sales. Li et al. (2019) found that for small firms, advertising expenditures positively impacted their annual gross sales, a trend that was not observed for large firms. Regarding business practices, Campbell and Hall (2010) addressed the relationship between specific plant category sales and price variables, demand factors, business characteristics, and selling characteristics. Many of the plant categories had an increase in gross sales if the percent of wholesale sales increased. Cost of production and product inventory were positively related to gross sales, while other growers' prices were inversely related to gross sales. Behe et al. (2008) addressed regional nursery business practices in the United States. Across regions, in-person sales dominated the industry, followed by telephone sales. Price was primarily influenced by production-level costs, plant grade, and market demand. Geographical expansion was limited by production, personnel, and marketing. As highlighted by this research, many factors influence green industry firms' decisions on advertising and business strategies, and those decisions ultimately impact their firms' performance. Similar topics have not been addressed for the landscape service sector of the green industry. This study aims to address this knowledge gap.

In a recent study, Torres et al. (2017) reported on the marketing and advertising activities of landscape service firms, some of which had diversified their offerings with other business functions (e.g., engaged in wholesale production and retail sales). The study showed landscape businesses spent, on average, $5.6 \%$ of total sales on advertising, with larger landscape companies spending two to three times the percentage of sales on advertising compared with small and medium firms. Advertising as a percent of sales was three to four times higher for diversified landscape firms that included production, service, and retail functions compared with businesses that provided service only or services with a retail function. In that study, most respondents used Internet advertising as their primary method of advertising.

Before Torres et al. (2017), scant publicly available literature explored any marketing or management aspects of this economically important industry sector. One of the few peerreviewed publications about landscape marketing business practices was published nearly 30 years ago from a survey of 62 Georgia landscape architects (Garber and Bondari, 1992a, 1992b, 1992c). The study showed that $85 \%$ of the landscape firms' sales were instate, but $47 \%$ of the material specified was sourced out-of-state. More recent studies discussed the importance of labor to the landscape service businesses. Haynes et al. (2007) showed that within the service sector, landscape installation and general maintenance were the primary services offered. They also found the ability to hire qualified personnel was the most limiting factor for the service sector (Haynes et al., 2007). The 2016 Lawn and Landscape State of the Industry report found quality labor was the biggest concern of respondents (45\%; Lawn and Landscape, 2016). These results were consistent with 
Table 1. Summary statistics for U.S. landscape service firms, from the 2014 and 2019 National Green Industry Surveys.

\begin{tabular}{|c|c|c|c|c|c|c|c|}
\hline Firm statistics & \multicolumn{2}{|r|}{ U.S. ${ }^{z}$} & \multicolumn{2}{|c|}{ Total sample } & \multicolumn{2}{|c|}{ SY2014 } & SY2019 \\
\hline $\mathrm{n}$ & \multicolumn{2}{|c|}{505,000} & \multicolumn{2}{|c|}{564} & \multicolumn{2}{|c|}{135} & 429 \\
\hline $\begin{array}{l}\text { Annual revenue } \\
\text { (U.S. dollars) }\end{array}$ & \multicolumn{2}{|c|}{$\$ 800,000.00$} & \multicolumn{2}{|c|}{$\$ 1,780,997.00$} & \multicolumn{2}{|c|}{$\$ 3,774,993.00$} & $\$ 1,153,515.00^{*}$ \\
\hline No. of employees (average) & \multicolumn{2}{|c|}{7.0} & \multicolumn{2}{|c|}{14.8} & \multicolumn{2}{|c|}{14.5} & 14.8 \\
\hline Regions & Rank & $\%$ & Regions & Rank & $\%$ & $\%$ & $\%$ \\
\hline Southeast & 1 & $24.9 \%$ & Midwest & 1 & $33.3 \%$ & $30.4 \%$ & $34.3 \%$ \\
\hline Mid-Atlantic & 2 & $18.2 \%$ & Southeast & 2 & $22.0 \%$ & $31.1 \%$ & $19.1 \% *$ \\
\hline Great Lakes & 3 & $15.3 \%$ & Northeast & 3 & $10.3 \%$ & $6.7 \%$ & $11.4 \%$ \\
\hline West & 4 & $13.7 \%$ & Appalachian & 4 & $8.3 \%$ & $6.7 \%$ & $8.9 \%$ \\
\hline New England & 5 & $8.5 \%$ & Southcentral & 5 & $8.0 \%$ & $0.7 \%$ & $10.3 \% *$ \\
\hline Southwest & 6 & $7.4 \%$ & Pacific & 6 & $7.8 \%$ & $17.0 \%$ & $4.9 \% *$ \\
\hline Plains & 7 & $7.3 \%$ & Mountain & 7 & $5.5 \%$ & $0.7 \%$ & $7.0 \% *$ \\
\hline Rocky Mountain & 8 & $4.7 \%$ & Great Plains & 8 & $4.8 \%$ & $6.7 \%$ & $4.2 \%$ \\
\hline
\end{tabular}

${ }^{\mathrm{z}}$ Source: Diment, 2020 .

*Indicates significances at the 5\% level between survey years (SY2014, SY2019) from analysis of variance and Tukey's honestly significant difference test.

Florkowski and Landry (2000), who reported that labor was the major expense and concern of landscape firms. Although both studies address general landscape service business-related questions, neither delve into specific marketing, advertising, or business practices and how they vary by landscape industry sector (i.e., wholesaler, retailer, etc.) or firm size.

Advertising is a key business marketing function for most firms. Eid and El-Gohary (2013) reported that Internet marketing and e-mail marketing were the most used e-marketing tools by small businesses and that adoption of those tools has a positive impact on the success of those businesses. Furthermore, Cole et al. (2017) found that a company website, social media, and email marketing were the top three digital marketing strategies employed by small businesses. Information about business practices, product mix, challenges facing business growth and management, establishment of prices, sales methods, and advertising is rare for this important sector of the green industry. Yet, sparse literature documents and facilitates a contemporary understanding of the marketing and management activities of firms that provide

Received for publication $11 \mathrm{Feb}$. 2021. Accepted for publication 5 Apr. 2021.

Published online 27 May 2021

We thank the Horticultural Research Institute, which provided funding essential for data collection in 2019. We also thank the members of the S-1065 Regional Project for the data, especially Alan Hodges, University of Florida, who led the survey data collection and dataset verification efforts.

Researcher salary for this project was supported by the U.S. Department of Agriculture, National Institute of Food and Agriculture, Hatch Project Number MICL 02085 and by Michigan State University AgBioResearch.

A.L.R. is an Assistant Professor.

A.T. is an Assistant Professor.

S.S.B. is a Professor and Extension Specialist.

B.K.B. is a Professor.

H.K. is an Associate Professor.

A.L.R. is the corresponding author. E-mail: arihn@utk.edu.

This is an open access article distributed under the CC BY-NC-ND license (https://creativecommons. org/licenses/by-nc-nd/4.0/). landscape services. Given the importance of landscapers in the green industry and with little research documenting their business practices, investigators set out to build upon Torres et al. (2017) by examining data collected in 2014 and 2019 to describe the marketing and business practices of U.S. landscape service providers. Drawing on data from the 2014 and 2019 National Green Industry Surveys, the objective of this article is to document and describe the marketing practices used and external factors that impact landscape service businesses. Specifically, we investigate advertising types and expenditures by firm size, and factors that impact landscape services' price formation, geographic range, and overall business strategies.

\section{Materials and Methods}

Two different survey datasets were used in this study. The 2014 National Green Industry Survey gathered information on business practices for calendar year 2013 or fiscal year 2013-14. The 2019 National Green Industry Survey was conducted in mid-2019 and collected information on business practices for 2018 or fiscal year 2018-19. The 2019 questionnaire used questions from previous studies (Hodges et al., 2015a, 2015b) and gained approval from the University of Florida Institutional Review Board for compliance with ethical standards for human subjects research for the questionnaire and survey protocol.

These data collection efforts represent the sixth and seventh national survey conducted by the Green Industry Research Consortium, following previous surveys in 1989, 1994, 1999, 2004, and 2009 (Brooker and Turner, 1990; Brooker et al., 2000, 2005; Hodges et al., 2010). The 2014 and 2019 surveys incorporated new questions regarding landscaping service firms and retail marketing practices (Hall et al., 2020; Hodges et al., 2015a, 2015b). This research study used the 2014 and 2019 datasets to provide a time series perspective of landscape service firms' marketing, advertising, and business practices in the United States. Using the two datasets provided the benefit of a large sample size, which allowed for an in-depth investigation on the relationship between firm type and size on landscape firms' use of the different practices. Differences across survey years are also provided.

The main sections of the survey included questions about nursery and greenhouse business practices such as employment, annual sales, product types sold, market outlets, selling methods, advertising expenditures, and product distribution by state or country. Following the previous survey methodology, the survey targeted horticultural retailers and landscape service providers as well as wholesale growers, asking them detailed questions about the use of digital marketing tools. Contact lists of firms for the survey were obtained from the state agricultural agencies responsible for phytosanitary inspection and licensing of plant businesses.

The contact list from 2014 contained over 104,000 firms, of which 32,000 firms were contacted to complete the survey, with 15,000 receiving mailed questionnaires and 17,000 receiving electronic survey links via e-mail (Hodges et al., 2015a). For the 2019 survey, the contact list contained over 51,933 firms from across all 50 states, from which a sample of 43,877 firms was selected for the survey, including 14,995 randomly selected firms receiving mailed questionnaires and 28,882 firms with valid e-mail addresses that were contacted via e-mail (Khachatryan et al., 2020). The number of firms within each contact list and number of contacted firms varied by survey year partially due to firms starting or disbanding over the years and based on funding availability for the research. Each firm initially received an introductory postcard, followed by two mailings of the survey instrument and reminder postcard messages (Dillman, 2000). The analysis was conducted using Stata version 16.1 (release 2019; StataCorp, College Station, TX). We made multiple comparisons among means in the analysis of variance (ANOVA) models using Tukey's honestly significant difference (HSD) method at the $5 \%$ significance level.

The data from the 2014 and 2019 surveys were used for this analysis, and business practices of landscape businesses were compared across years. In 2014, a total of 2657 firms responded to the survey. For the sample 
Table 2. Proportion of landscape businesses responding to the 2014 and 2019 National Green Industry Surveys, categorizedy business type and firm size.

\begin{tabular}{|c|c|c|c|c|c|c|c|c|c|c|c|c|}
\hline \multirow[b]{2}{*}{$\operatorname{Size}^{\mathrm{z}}$} & \multicolumn{3}{|c|}{ Full sample } & \multicolumn{3}{|c|}{$\mathrm{LO}^{\mathrm{y}}$} & \multicolumn{3}{|c|}{$\mathrm{LR}^{\mathrm{x}}$} & \multicolumn{3}{|c|}{$\mathrm{LGR}^{\mathrm{w}}$} \\
\hline & $\begin{array}{c}\text { Total } \\
\%\end{array}$ & $\begin{array}{c}\text { SY2014 } \\
\%\end{array}$ & $\begin{array}{c}\text { SY2019 } \\
\%\end{array}$ & $\begin{array}{c}\text { Total } \\
\%\end{array}$ & $\begin{array}{c}\text { SY2014 } \\
\%\end{array}$ & $\begin{array}{c}\text { SY2019 } \\
\%\end{array}$ & $\begin{array}{c}\text { Total } \\
\%\end{array}$ & $\begin{array}{c}\text { SY2014 } \\
\%\end{array}$ & $\begin{array}{c}\text { SY2019 } \\
\%\end{array}$ & $\begin{array}{c}\text { Total } \\
\%\end{array}$ & $\begin{array}{c}\text { SY2014 } \\
\%\end{array}$ & $\begin{array}{c}\text { SY2019 } \\
\%\end{array}$ \\
\hline Small & 0.236 & 0.178 & 0.254 & 0.267 & 0.207 & 0.283 & 0.202 & 0.200 & 0.202 & 0.207 & 0.140 & 0.241 \\
\hline Large & 0.319 & 0.282 & 0.331 & 0.303 & 0.207 & 0.327 & 0.421 & 0.400 & 0.426 & 0.278 & 0.316 & 0.259 \\
\hline n & 564 & 135 & 429 & 281 & 58 & 223 & 114 & 20 & 94 & 169 & 57 & 112 \\
\hline
\end{tabular}

${ }^{\mathrm{z}}$ Firm size was determined on estimated annual sales amounts reported by participating firms and consisted of small (\$10,000 to $\$ 124,999$ in sales), medium $(\$ 125,000$ to $\$ 749,999)$, and large $(\$ 750,000+)$ firms.

${ }^{\mathrm{y}} \mathrm{LO}$ firms are those indicating they only provide landscape services.

${ }^{x}$ LR firms are those indicating they provide landscape services and retailing.

${ }^{\mathrm{w}}$ LGR firms are those indicating they provide landscape services, wholesale production (growers), and retailing.

*Indicates significances at the 5\% level between survey years (SY2014, SY2019) from analysis of variance and Tukey's honestly significant difference test.

results from the 2014 survey, please see Hodges et al. (2015a). In 2019, a total of 2170 usable questionnaires were returned, representing an overall $4.9 \%$ response rate, including 1141 respondents by mail (a $7.6 \%$ response rate) and 1029 by e-mail (a 3.6\% response rate). This study focused on firms indicating they had a landscaping component to their businesses, leaving a total of 871 firms for the analysis. Subsequently, firms with
$<\$ 10,000$ in revenue were eliminated because they were below the threshold that might constitute an independent "viable" small firm (302 firms were below this threshold). Additionally, five firms were removed from the sample for potential duplication between the two survey years. Potential duplicates were identified through comparing firm characteristics, including business zip code, year of establishment, firm type, and estimated annual sales. Five firms were identified as overlapping in the zip code, year of establishment, and firm type variables. These firms' estimated annual sales were also comparable (although not exact matches) across the two datasets, indicating potential duplicates. As a result, the sample for this study included 564 landscape firms for analysis of business practices among landscape service firms.

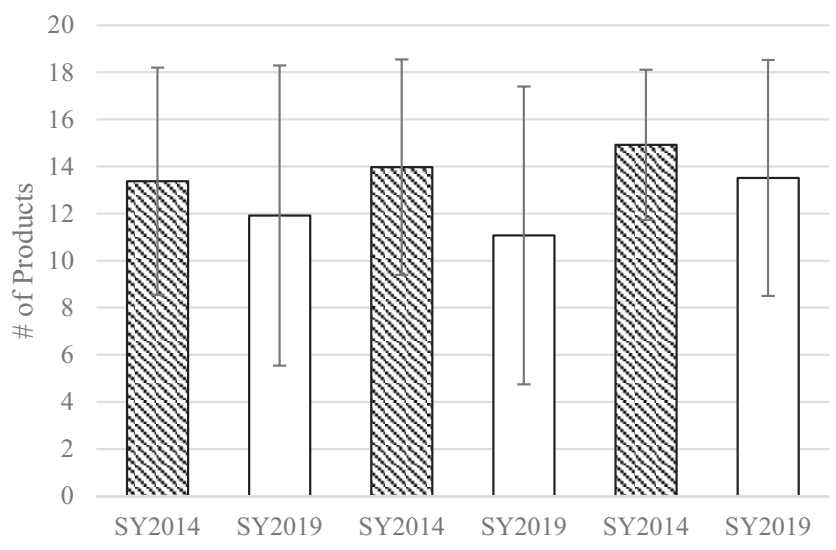

(A) Total Sample

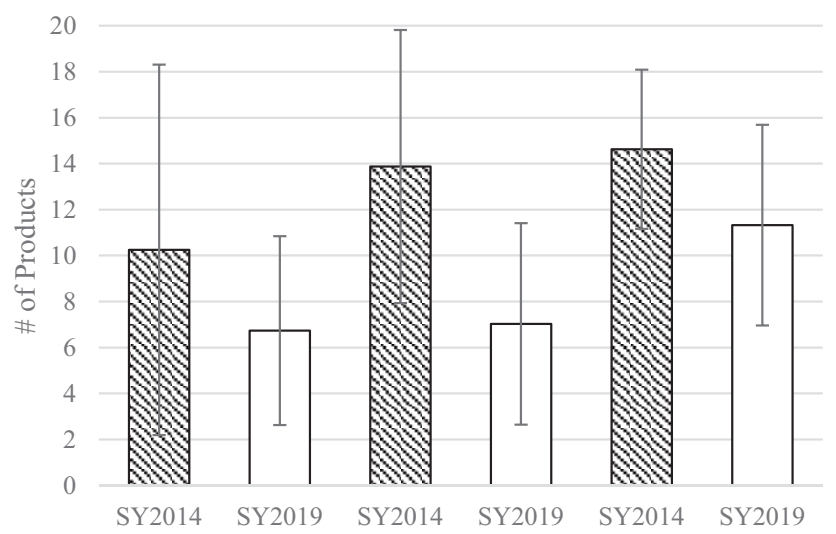

(C) Landscape Retail (LR) Firms

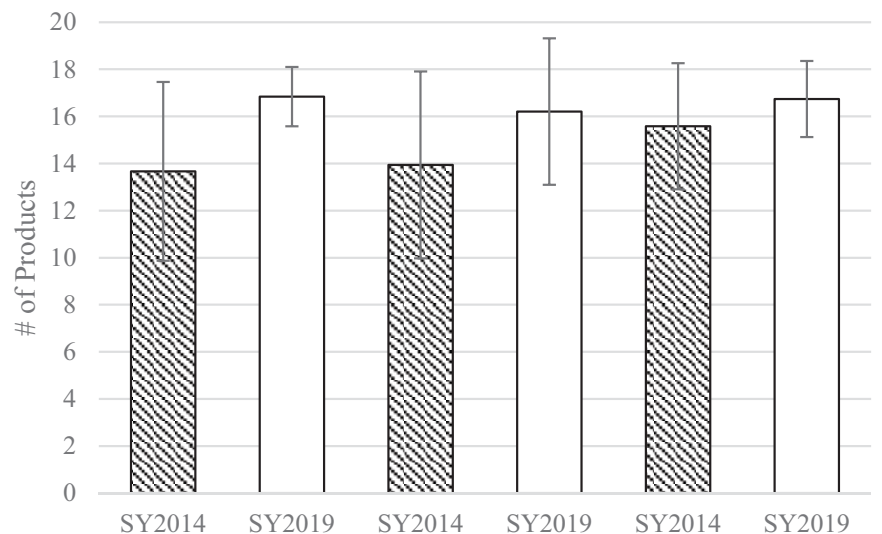

(B) Landscape Only (LO) Firms

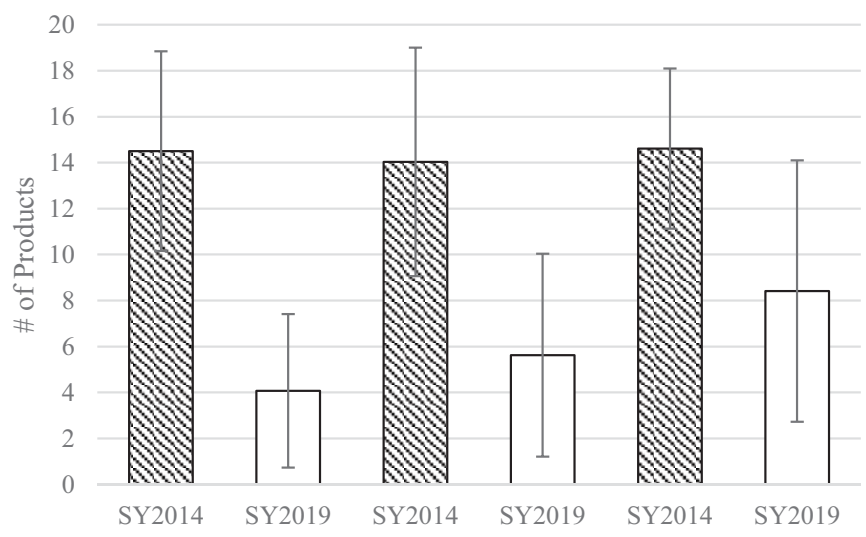

(D) Landscape, Wholesale (grower), Retail (LGR) Firms

Fig. 1. Average number of different plant types carried, by firm type, firm size, and survey year. The mean diversity score was calculated by adding together all of the product types from Table 3 for each firm (where $1=>0 \%$ sales; $0=0 \%$ sales). A total of 17 different products were available, and the number of products is used to represent product diversity. Significance was tested among the following: 1) mean number of plant types by firm size within each firm type, 2) average number of plant types by firm type, and 3) between survey years using analysis of variance and Tukey's honestly significant difference test. 
Table 3. Mean number of products sold by four types of landscaping firms (landscape only, landscape retail, and landscape production and retail) by year

\begin{tabular}{|c|c|c|c|c|c|c|c|c|}
\hline \multirow[b]{3}{*}{$\operatorname{Size}^{\mathrm{z}}$} & \multicolumn{4}{|c|}{ Full sample } & \multicolumn{4}{|c|}{$\mathrm{LO}^{\mathrm{y}}$} \\
\hline & \multicolumn{2}{|c|}{ SY2014 } & \multicolumn{2}{|c|}{ SY2019 } & \multicolumn{2}{|c|}{ SY2014 } & \multicolumn{2}{|c|}{ SY2019 } \\
\hline & $\mathrm{n}$ & Mean & $\mathrm{n}$ & Mean & $\mathrm{n}$ & Mean & $\mathrm{n}$ & Mean \\
\hline Small & 24 & 13.375 & 109 & 11.917 & 12 & 13.667 & 63 & $16.841^{*}$ \\
\hline Medium & 73 & 13.973 & 178 & $11.073 *$ & 34 & 13.941 & 87 & $16.207 *$ \\
\hline Large & 38 & 14.921 & 142 & 13.514 & 12 & 15.583 & 73 & $16.740^{*}$ \\
\hline $\mathrm{Size}^{\mathrm{z}}$ & $\mathrm{n}$ & Mean & $\mathrm{n}$ & Mean & $\mathrm{n}$ & Mean & $\mathrm{n}$ & Mean \\
\hline$\overline{\text { All }}$ & 20 & 13.450 & 94 & $8.798^{*}$ & 57 & 14.281 & 112 & $5.973^{*}$ \\
\hline Small & 4 & 10.250 & 19 & 6.737 & 8 & 14.500 & 27 & $4.074^{*}$ \\
\hline Medium & 8 & 13.875 & 5 & $7.029 *$ & 31 & 14.032 & 56 & $5.625^{*}$ \\
\hline Large & 8 & 14.625 & 40 & $11.325^{*}$ & 18 & 14.611 & 29 & $8.414^{*}$ \\
\hline
\end{tabular}

${ }^{\mathrm{z}}$ Firm size was determined on estimated annual sales amounts reported by participating firms and consisted of small (\$10,000 to $\$ 124,999$ in sales), medium $(\$ 125,000$ to $\$ 749,999)$, and large $(\$ 750,000+)$ firms.

${ }^{\mathrm{y}} \mathrm{LO}$ firms are those indicating they only provide landscape services.

${ }^{\mathrm{x}} \mathrm{LR}$ firms are those indicating they provide landscape services and retailing.

${ }^{\mathrm{w}}$ LGR firms are those indicating they provide landscape services, wholesale production (growers), and retailing.

*Indicates significances at the 5\% level between survey years (SY2014, SY2019) from analysis of variance and Tukey's honestly significant difference test.

\section{Results and Discussion}

Firms reported on average $\$ 1.78 \mathrm{M}$ in annual sales, with the 2014 participants reporting higher sales than the 2019 participants (Table 1). The reported annual sales of the surveyed firms were higher than the national average, potentially due to the exclusion of the smaller $(<\$ 10 \mathrm{~K}$ in sales $)$ firms. This assumption is supported by the lower number of employees ( 7 employees) of the national sample relative to the surveyed firms (14 employees). At least some of the differences between 2014 and 2019 can be attributed to the larger sample used in 2019.

Responses were received from all 50 states, with the largest number of responses from the Southeast, Midwest, and Northeast U.S. regions, representing $63 \%$ of the responses $(n=564)$, while the fewest responses were obtained from the Mountain and Great Plains regions (10.3\%; Table 1). The sample was fairly consistent with the national geographic distribution of landscaping firms, in that the Southeast, MidAtlantic, and Great Lakes regions accounted for the majority of the industry's concentration $(58.4 \%)$, while the Plains and Rocky Mountains accounted for the lowest concentration (12.0\%) (Diment, 2020).

Table 4. Percent of products sold by U.S. landscape firms, from the 2014 and 2019 National Green Industry Surveys, by business type and survey year.

\begin{tabular}{|c|c|c|c|c|c|c|c|c|c|c|c|c|}
\hline \multirow[b]{2}{*}{ Product sold ${ }^{\mathrm{z}}$} & \multicolumn{3}{|c|}{ Full sample } & \multicolumn{3}{|c|}{$\mathrm{LO}^{\mathrm{y}}$} & \multicolumn{3}{|c|}{$\operatorname{LR}^{\mathrm{x}}$} & \multicolumn{3}{|c|}{$\mathrm{LGR}^{\mathrm{w}}$} \\
\hline & $\begin{array}{c}\text { Total } \\
\%\end{array}$ & $\begin{array}{c}\text { SY2014 } \\
\%\end{array}$ & $\begin{array}{c}\text { SY2019 } \\
\%\end{array}$ & $\begin{array}{c}\text { Total } \\
\%\end{array}$ & $\begin{array}{c}\text { SY2014 } \\
\%\end{array}$ & $\begin{array}{c}\text { SY2019 } \\
\%\end{array}$ & $\begin{array}{c}\text { Total } \\
\%\end{array}$ & $\begin{array}{c}\text { SY2014 } \\
\%\end{array}$ & $\begin{array}{c}\text { SY2019 } \\
\%\end{array}$ & $\begin{array}{c}\text { Total } \\
\%\end{array}$ & $\begin{array}{c}\text { SY2014 } \\
\%\end{array}$ & $\begin{array}{c}\text { SY2019 } \\
\%\end{array}$ \\
\hline Deciduous tree $\mathrm{e}^{\mathrm{ab}}$ & 0.887 & 0.941 & $0.869^{*}$ & 0.986 & 0.966 & 0.991 & 0.807 & 0.900 & 0.787 & 0.775 & 0.930 & $0.696^{*}$ \\
\hline Deciduous shrub ${ }^{\text {ab }}$ & 0.839 & 0.919 & $0.814 *$ & 0.979 & 0.948 & 0.987 & 0.754 & 0.850 & 0.734 & 0.663 & 0.912 & $0.536^{*}$ \\
\hline Broad-leaved evergreen shrub ${ }^{\text {ab }}$ & 0.812 & 0.889 & $0.788^{*}$ & 0.968 & 0.931 & 0.978 & 0.702 & 0.800 & 0.681 & 0.627 & 0.877 & $0.500^{*}$ \\
\hline Herbaceous perennial $^{\text {abc }}$ & 0.812 & 0.948 & $0.769 *$ & 0.975 & 0.983 & 0.973 & 0.737 & 0.900 & 0.702 & 0.592 & 0.930 & $0.420 *$ \\
\hline Bedding plants- flowering annuals ${ }^{\mathrm{ab}}$ & 0.773 & 0.867 & $0.744 *$ & 0.961 & 0.897 & $0.978^{*}$ & 0.623 & 0.800 & 0.585 & 0.562 & 0.860 & $0.411^{*}$ \\
\hline $\operatorname{Roses}^{\mathrm{abc}}$ & 0.750 & 0.837 & $0.723^{*}$ & 0.954 & 0.879 & $0.973 *$ & 0.623 & 0.700 & 0.606 & 0.497 & 0.842 & $0.321 *$ \\
\hline Bedding plants-veg, fruit, herb ${ }^{a b c}$ & 0.730 & 0.778 & 0.716 & 0.918 & 0.707 & $0.973 *$ & 0.614 & 0.800 & 0.574 & 0.497 & 0.842 & $0.321 *$ \\
\hline Flowering potted plants ${ }^{\mathrm{ab}}$ & 0.706 & 0.800 & $0.676^{*}$ & 0.936 & 0.776 & $0.978^{*}$ & 0.491 & 0.800 & $0.426^{*}$ & 0.467 & 0.825 & $0.286^{*}$ \\
\hline Fruit trees ${ }^{\mathrm{ab}}$ & 0.686 & 0.763 & $0.662 *$ & 0.922 & 0.759 & $0.964 *$ & 0.509 & 0.750 & $0.457 *$ & 0.414 & 0.772 & $0.232 *$ \\
\hline $\operatorname{Sod}^{\text {ab }}$ & 0.668 & 0.822 & $0.620 *$ & 0.961 & 0.879 & $0.982 *$ & 0.351 & 0.750 & $0.266^{*}$ & 0.396 & 0.789 & $0.196^{*}$ \\
\hline Foliage $^{\mathrm{ab}}$ & 0.645 & 0.689 & 0.632 & 0.907 & 0.672 & $0.969 *$ & 0.395 & 0.650 & $0.340^{*}$ & 0.379 & 0.719 & $0.205^{*}$ \\
\hline
\end{tabular}

${ }^{\mathrm{z}}$ To identify the proportion of firms carrying the different plant types, firms who indicated $>0 \%$ sales for that specific plant type were assigned a 1 ; while firms with $0 \%$ sales for that specific plant type were assigned 0 . Significant differences between firm types and survey years were tested using analysis of variance and Tukey's honestly significant difference test.

${ }^{\mathrm{y}} \mathrm{LO}$ firms are those indicating they only provide landscape services.

${ }^{\mathrm{x}} \mathrm{LR}$ firms are those indicating they provide landscape services and retailing.

${ }^{\mathrm{w}}$ LGR firms are those indicating they provide landscape services, wholesale production (growers), and retailing.

andicates significance between the total samples of LO and LGR at $5 \%$.

${ }^{\mathrm{b}}$ Indicates significance between the total samples of LO and LR at $5 \%$.

${ }^{\mathrm{c}}$ Indicates significance between the total samples of LGR and LR at $5 \%$.

*Indicates significances at the 5\% level between survey years (SY2014, SY2019). 
Table 5. Comparison of percent of business generated by method of sales for U.S. landscape firms by business type, from the 2014 and 2019 National Green Industry Surveys.

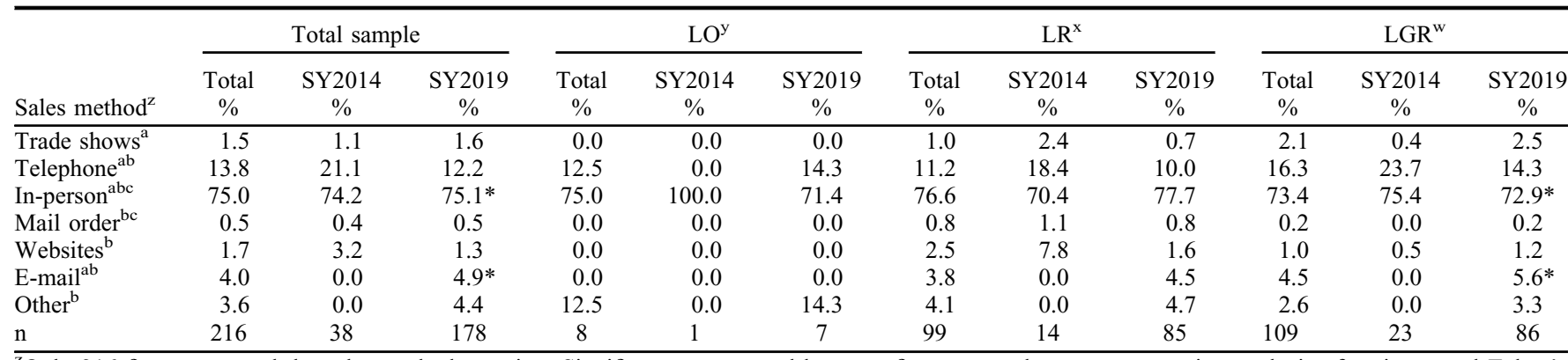

${ }^{\mathrm{z} O n l y} 216$ firms answered the sales method question. Significance was tested between firm type and survey years using analysis of variance and Tukey's honestly significant difference test.

${ }^{\mathrm{y}} \mathrm{LO}$ firms are those indicating they only provide landscape services.

${ }^{\mathrm{x}} \mathrm{LR}$ firms are those indicating they provide landscape services and retailing.

${ }^{\mathrm{w}}$ LGR firms are those indicating they provide landscape services, wholesale production (growers), and retailing.

${ }^{a}$ Indicates significance between the total samples of LO and LGR firms at 5\%.

${ }^{\mathrm{b}}$ Indicates significance between the total samples of LO and LR firms at 5\%.

${ }^{\mathrm{c}}$ Indicates significance between the total samples of LGR and LR firms at $5 \%$.

*Indicates significances at the 5\% level between survey years (SY2014, SY2019).

The sample was further divided into size categories by sales volume and by business type (Table 2). Firm sizes were based on Torres et al. (2017), with small firms reporting $\$ 10,000$ to $\$ 124,999$ in sales volume; medium firms had $\$ 125,000$ to $\$ 749,999$ in sales volume; and large firms had at least $\$ 750,000$ in sales as well as the sample distribution across the size categories. The firm type categories included landscape businesses identifying themselves as providers of landscape services only (LO); landscape services and retailing (LR); and landscape services, wholesale production (grower), and retailing (LGR). Half of all sampled firms $(49.8 \%)$ were service providers only (LO) and had not diversified into other business functions (e.g., wholesale production or retail) (Table 2). About $20 \%$ of landscape businesses had diversified into retailing (LR), while $30 \%$ of operations included diversification into wholesale and retail sales (LGR) in combination with landscape services. In comparison, the 2014 survey showed $49.2 \%$ of the firms were landscape only (LO) and $18.3 \%$ were highly diversified (LGR). When making comparisons of diversification by size, results showed an interesting dichotomy where the medium-sized firms demonstrated the highest proportion of diversified operations compared with small- and large-sized firms (Table 2). Perhaps medium firms use sales diversification strategies to grow in sales volume from small to medium size. Alternatively, small firms had a higher proportion of LO operations. In the
LO operations, the 2014 survey sample consisted of a larger portion of medium firms relative to the 2019 survey sample.

Generally, we found differences in the number of plant types sold between the two surveys and across firm type and firm size categories (Table 3). In most cases, participants in the 2014 survey indicated greater diversity than participants in the 2019 survey; however, this varied by firm type, with LR and LGR exhibiting a similar trend to the total sample, while LO firms had greater diversity in the 2019 survey than in the 2014 survey. The undiversified LO firms sold the most diversified product mix with $>89 \%$ of those firms selling each type of plant listed in the study. An explanation may be that the

Table 6. U.S. Landscaping firms' advertising expenditures (U.S. dollars), by firm type and size, from the 2014 and 2019 National Green Industry Surveys.

\begin{tabular}{|c|c|c|c|c|c|c|c|c|c|c|c|c|}
\hline \multirow[b]{2}{*}{$\operatorname{Size}^{\mathrm{z}}$} & \multicolumn{6}{|c|}{ Total sample ${ }^{\mathrm{ab}}$} & \multicolumn{6}{|c|}{$\mathrm{LO}^{\text {aby }}$} \\
\hline & $\mathrm{n}$ & Mean & $\mathrm{n}$ & Mean & $\mathrm{n}$ & Mean & $\mathrm{n}$ & Mean & $\mathrm{n}$ & Mean & $\mathrm{n}$ & Mean \\
\hline Medium & 133 & $\$ 7,329.93$ & 73 & $\$ 3,597.26$ & 60 & $\$ 11,871.33^{*}$ & 36 & $\$ 3,527.78$ & 34 & $\$ 2,816.18$ & 2 & $\$ 15,625.00^{*}$ \\
\hline Small & 56 & $\$ 3,611.63$ & 24 & $\$ 1,758.75$ & 32 & $\$ 5,001.28^{*}$ & 12 & $\$ 1,285.00$ & 12 & $\$ 1,285.00$ & 0 & - \\
\hline Total & 285 & $\$ 121,405.70$ & 135 & $\$ 175,218.70$ & 150 & $\$ 72,974.06$ & 63 & $\$ 73,336.19$ & 58 & $\$ 72,912.59$ & 5 & $\$ 78,250.00$ \\
\hline $\operatorname{Size}^{\mathrm{z}}$ & $\mathrm{n}$ & Mean & $\mathrm{n}$ & Mean & $\mathrm{n}$ & Mean & $\mathrm{n}$ & Mean & $\mathrm{n}$ & Mean & $\mathrm{n}$ & Mean \\
\hline$\overline{\text { Large }}$ & 42 & $\$ 255,517.60$ & 8 & $\$ 696,250.00$ & 34 & $\$ 151,815.90^{*}$ & 39 & $\$ 467,025.60$ & 18 & $\$ 758,997.20$ & 21 & $\$ 216,764.20$ \\
\hline Medium & 33 & $\$ 8,721.97$ & 8 & $\$ 7,343.75$ & 25 & $\$ 9,163.00$ & 64 & $\$ 8,750.86$ & 31 & $\$ 3,487.10$ & 33 & $\$ 13,695.61^{*}$ \\
\hline Small & 17 & $\$ 3,803.35$ & 4 & $\$ 1,900.00$ & 13 & $\$ 4,389.00$ & 27 & $\$ 4,524.96$ & 8 & $\$ 2,398.75$ & 19 & $\$ 5,420.21$ \\
\hline Total & 92 & $\$ 120,480.70$ & 20 & $\$ 281,817.50$ & 72 & $\$ 75,664.89$ & 130 & $\$ 145,355.60$ & 57 & $\$ 241,916.50$ & 73 & $\$ 69,958.73$ \\
\hline
\end{tabular}

${ }^{\mathrm{z}}$ Firm size was determined on estimated annual sales amounts reported by participating firms and consisted of small (\$10,000 to $\$ 124,999$ in sales), medium $(\$ 125,000$ to $\$ 749,999)$, and large $(\$ 750,000+)$. Significance at the $5 \%$ level was tested using analysis of variance and Tukey's honestly significant difference test by firm size and survey year. No significant differences were observed between the types of businesses (LO, LR, LGR).

${ }^{\mathrm{y}} \mathrm{LO}$ firms are those indicating they only provide landscape services.

${ }^{\mathrm{x}} \mathrm{LR}$ firms are those indicating they provide landscape services and retailing.

${ }^{\mathrm{w}}$ LGR firms are those indicating they provide landscape services, wholesale production (growers), and retailing.

${ }^{\mathrm{a}}$ Indicates significance between small and large firms at $5 \%$.

${ }^{\mathrm{b}}$ Indicates significance between medium and large firms at $5 \%$.

*Indicates significances at the 5\% level between survey years (SY2014, SY2019). 


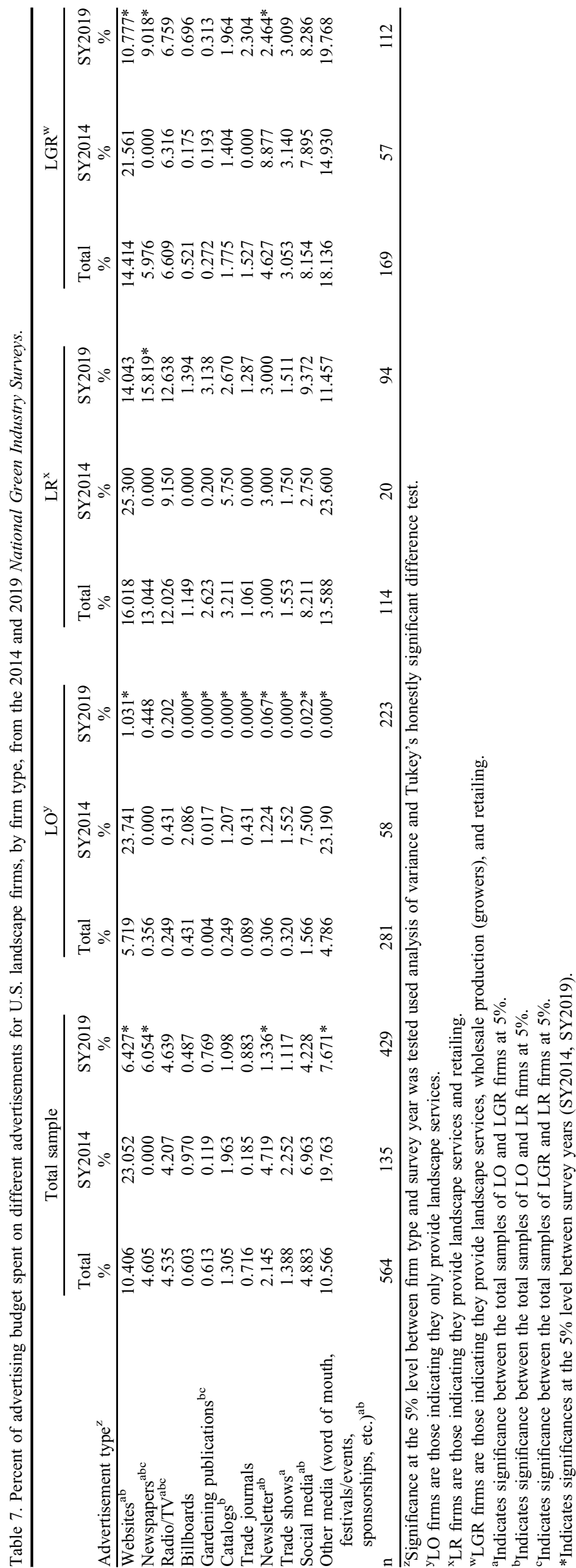

lack of production of LO firms (i.e., they do not grow plants) motivates them to purchase a wide variety of products for more immediate sales or installation. Interestingly, highly diversified firms (LGR) in terms of sales were the least diversified in product mix sales, selling on average a lower diversity of products than medium-diversified businesses (LR). The fact that LGR operations have less product diversification suggests that these businesses sell and plant primarily the products they grow.

We further examined the number of plants sold by business size (Fig. 1). Across the entire sample, the average firm sold 12.58 different types of plants (out of 17 options). Interestingly, larger firms sold, on average, more plant types compared with smallersized firms. Of note, most of the plant type diversification came from undiversified businesses (LO), who on average sold 16 plant types. This result may be due to the high percentage of service only firms selling all types of plants, even those from a small sales volume. LGR firms sold, on average, the fewest number of plant types (about 9 plants), and LR firms sold 9.6 plant types. Large and medium LGR firms sold a greater number of plant types than small LGR firms at 10.8, 8.6, and 6.5 plant types, respectively. Moderately diversified LR firms were midway between undiversified and highly diversified operations for the number of plant types sold. Thus, the average number of types of plants increased as firms increased in size and decreased as the sales' diversification level increased. Some differences were observed across survey years; for diversified firms (LR, LGR), a greater number of plant types were reported in 2014 than in 2019, regardless of firm size - except the LR small firms, which were insignificant $(P=0.204)$. Types of plants sold by firms varied by plant category and year (Table 4). Generally, a higher percentage of all firm types sold plants in 2014 compared with 2019 , most likely due to the difference in survey sampling. A greater percentage of LO firms sold most plant types, compared with LGR and LR firms.

Next, researchers investigated how landscape service firms used different sales methods, by business type category (Table 5). Sales methods included e-mail, in-person, mail order, trade shows, telephone, websites, and other strategies. Most sales were made inperson and differed by firm diversification level. LO firms relied primarily in sales via inperson, telephone, and other methods. E-mail was a contributing sales mechanism for LR firms, and in a lesser degree for LGR businesses. Overall, trade shows accounted for $2.1 \%$ of sales for LGR firms and $0.97 \%$ of sales for LR operations. Interestingly, LO firms did not report sales through trade shows. This makes intuitive sense because the service only firms would be unlikely to interact with end-consumers (either residential or commercial) at trade shows. Trade shows are primarily a mechanism for wholesale growers to sell to other businesses within the green industry. Few percentage sales $(1.65 \%)$ were generated 


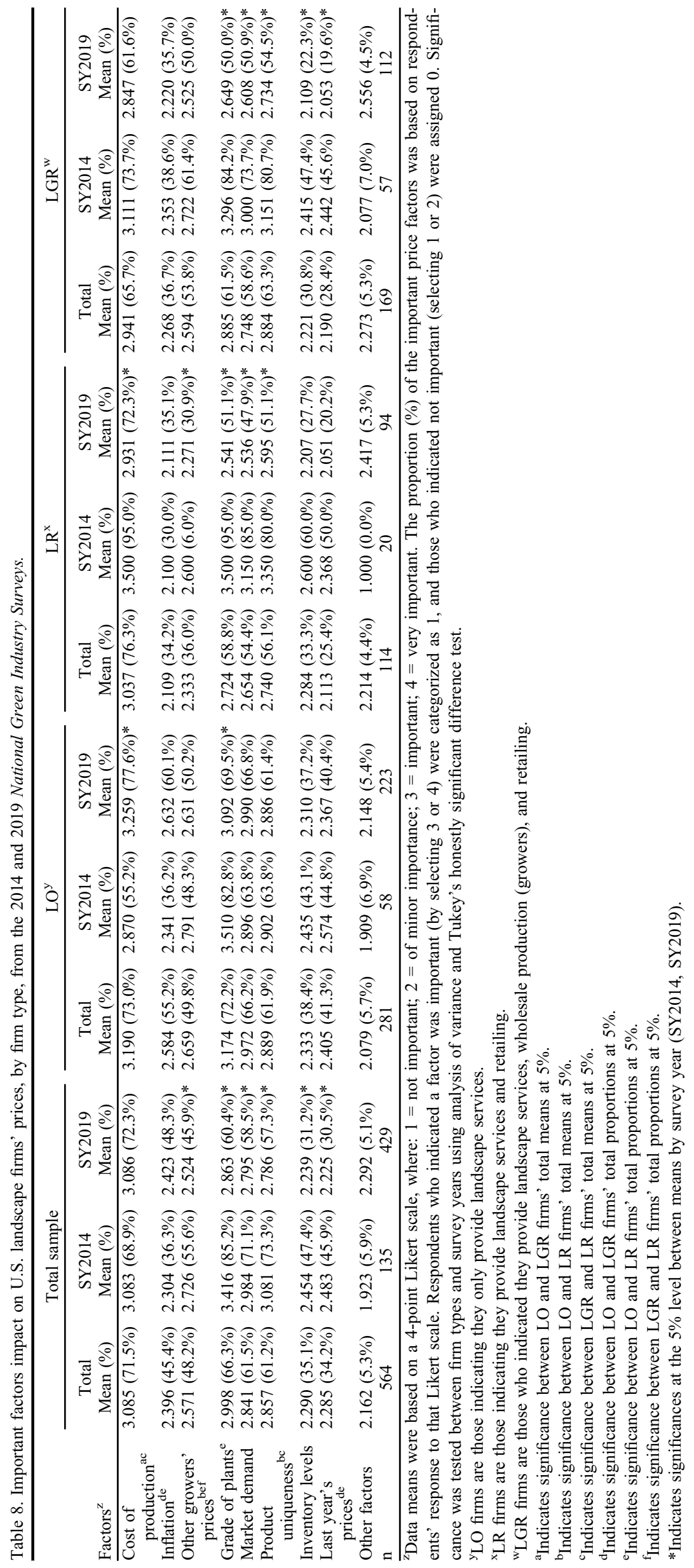

through websites for all firms, which was mainly reported by LGR and LR firms $(1.02 \%$ and $3.8 \%$, respectively).

Advertising expenditures by landscape firms averaged $\$ 121,405.70$ for the full sample (Table 6). Advertising expenditures increased by firm size and by diversification. Small firms spent 10 times less compared with large firms and half of the expenditures of medium firms. Highly diversified firms (LGR) spent more $(\$ 145,355.60)$ in advertising than LR operations $(\$ 120,480.70)$ and almost twice as much as undiversified LO firms $(\$ 73,336.19)$. The small LO firms spent almost half on advertising compared with the medium LO firms (at \$1285.00), which also spent about 30 times less than the amount invested by large LO businesses. Similar trends were reported for highly diversified firms by size comparison (LGR). The advertising investment gap between small and large LR was broader, with less than 10 times the difference in the amount invested on advertising expenditures between the smallest and largest firms.

Examining the firms by the percentage of advertising budget spent on different media types, several interesting differences were observed (Table 7). Across all firm types, expenditures on websites and other media were greatest, with over $10 \%$ of the advertising budget for each category. Website expenditures were at least twice as much as expenditures on newspapers, radio/TV, billboards, publications and catalogs, trade journals, newsletters, social media, and trade shows. Furthermore, operations selling retail (LR or LGR) spent more on digital marketing advertising (i.e., websites) compared with LO firms. With diversification into retail sales, advertising through websites reaches a relatively broad audience more efficiently when compared with other advertising methods. Firms devoted between $0.4 \%$ to $13.0 \%$ on print media, including newspapers, gardening publications, catalogs, trade journals, and newsletters. Across the print media options, landscape businesses with retail sales (LR) spent the most on newspapers $(13 \%)$ when compared with LGR $(6.0 \%)$ and LO $(0.4 \%)$ operations, which was predominately driven by 2019 respondents. The fact that LO businesses spent the least on most of the media advertising methods suggests that perhaps word-of-mouth is an effective advertising mechanism, which may account for the reduced expenditures on their advertising budgets. The percentage of advertising spent on radio or television was comparable to newspapers, but the medium diversified LR firm spent a substantially greater percentage on that medium $(12.0 \%)$, more than the other two firm types. Our results suggest that firms that participate in retail sales tend to use more new (online) and traditional media (radio and television) than firms not involved with retail sales. A greater investment in trade shows was made by the LGR firms compared with LO and LR businesses, which may reflect the fact that trade shows are useful advertising strategies for LGR business connecting with wholesalers and other consumer groups.

Survey respondents were asked to assess the importance of nine factors that may affect their prices. Table 8 presents the mean ratings 


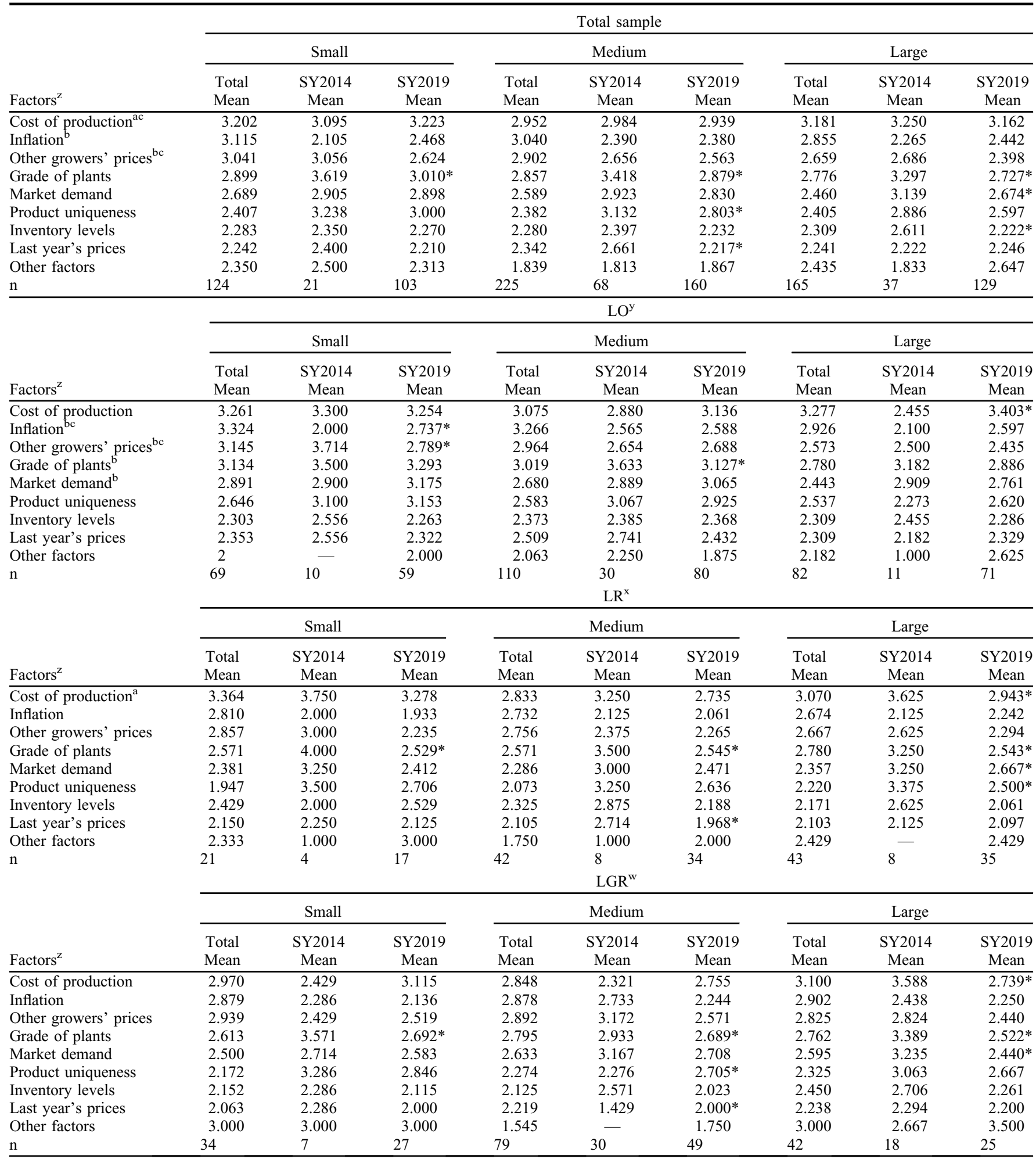

${ }^{\mathrm{z}}$ Data means were based on a 4-point Likert scale, where: $1=$ not important; $2=$ of minor importance; $3=$ important; $4=$ very important. Significance was tested between firm sizes within each firm type and survey years using analysis of variance and Tukey's honestly significant difference test.

${ }^{\mathrm{y}} \mathrm{LO}$ firms are those indicating they only provide landscape services.

${ }^{\mathrm{x}} \mathrm{LR}$ firms are those indicating they provide landscape services and retailing.

${ }^{\mathrm{w}}$ LGR firms are those indicating they provide landscape services, wholesale production (growers), and retailing.

'andicates significance between small and medium firms' total means at $5 \%$.

'Indicates significance between small and large firms' total means $5 \%$.

'Indicates significance between medium and large firms' total means at 5\%.

*Indicates significance at the $5 \%$ level between means by survey year (SY2014, SY2019). 


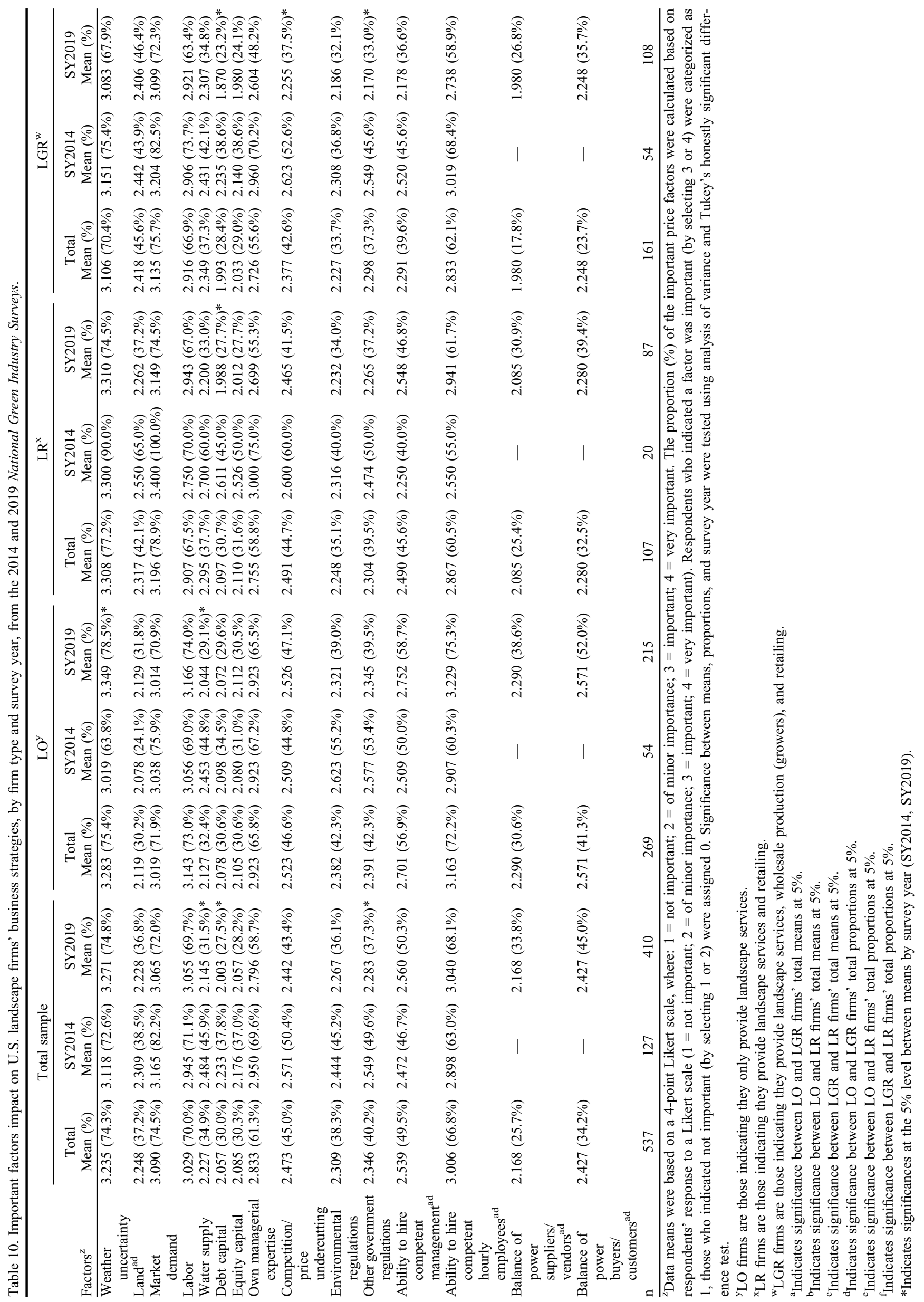


Table 11. Factors impacting U.S. landscape firms' business strategies, by firm type, size, and survey year, from the 2014 and 2019 National Green Industry Surveys.

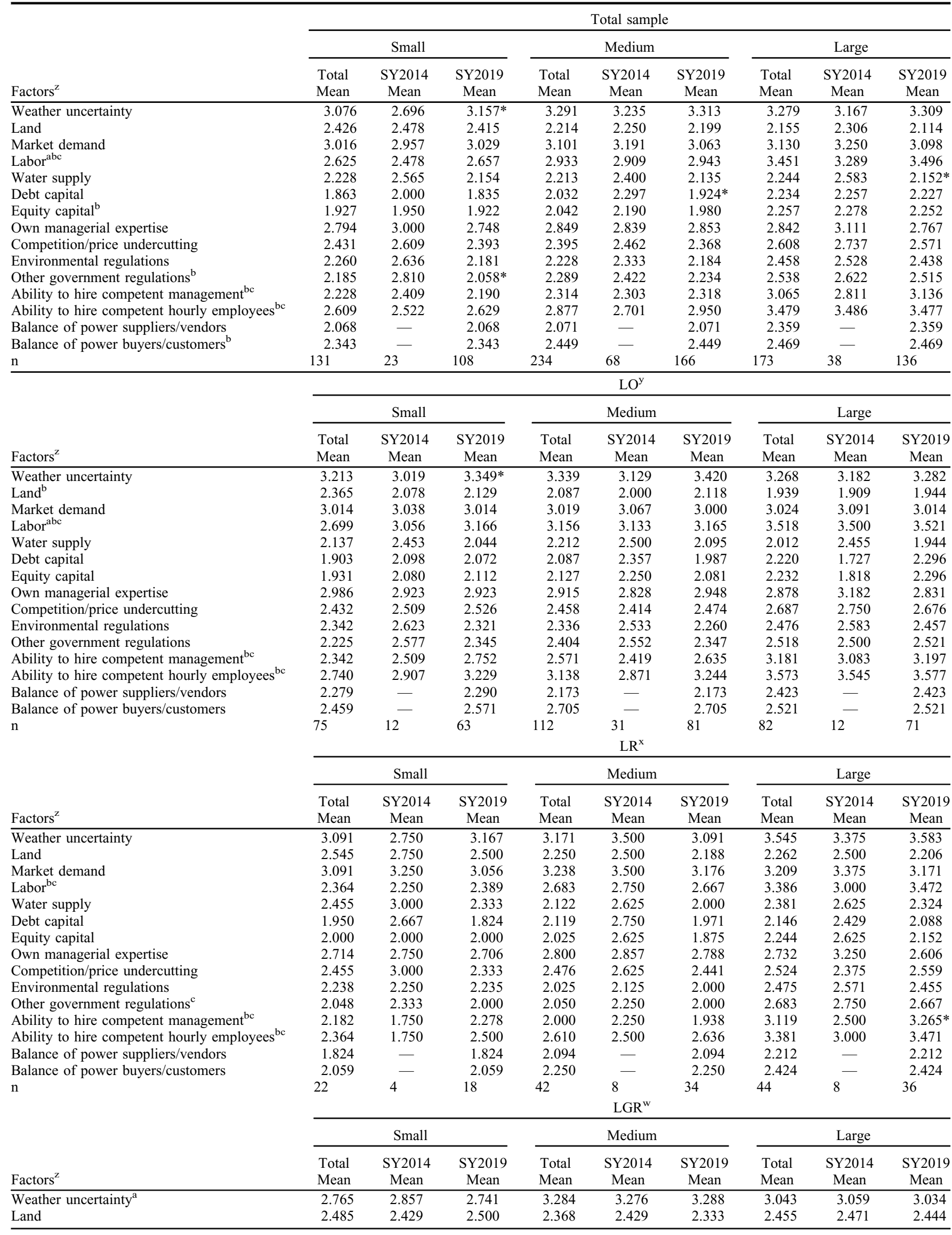

(Continued on next page) 


\begin{tabular}{|c|c|c|c|c|c|c|c|c|c|}
\hline \multirow[b]{3}{*}{ Factors $^{\mathrm{z}}$} & \multicolumn{9}{|c|}{$\mathrm{LGR}^{\mathrm{w}}$} \\
\hline & \multicolumn{3}{|c|}{ Small } & \multicolumn{3}{|c|}{ Medium } & \multicolumn{3}{|c|}{ Large } \\
\hline & $\begin{array}{l}\text { Total } \\
\text { Mean }\end{array}$ & $\begin{array}{c}\text { SY2014 } \\
\text { Mean }\end{array}$ & $\begin{array}{l}\text { SY2019 } \\
\text { Mean }\end{array}$ & $\begin{array}{l}\text { Total } \\
\text { Mean }\end{array}$ & $\begin{array}{l}\text { SY2014 } \\
\text { Mean }\end{array}$ & $\begin{array}{l}\text { SY2019 } \\
\text { Mean }\end{array}$ & $\begin{array}{l}\text { Total } \\
\text { Mean }\end{array}$ & $\begin{array}{l}\text { SY2014 } \\
\text { Mean }\end{array}$ & $\begin{array}{c}\text { SY2019 } \\
\text { Mean }\end{array}$ \\
\hline Market demand & 2.970 & 2.857 & 3.000 & 3.141 & 3.233 & 3.083 & 3.250 & 3.294 & 3.222 \\
\hline Labor bc & 2.636 & 2.714 & 2.615 & 2.747 & 2.714 & 2.766 & 3.391 & 3.278 & 3.464 \\
\hline Water supply & 2.281 & 2.714 & 2.160 & 2.263 & 2.222 & 2.286 & 2.545 & 2.647 & 2.481 \\
\hline Debt capital $^{b}$ & 1.719 & 2.000 & 1.654 & 1.907 & 2.107 & 1.787 & 2.341 & 2.529 & 2.222 \\
\hline Competition/price undercutting & 2.412 & 2.571 & 2.370 & 2.266 & 2.464 & 2.157 & 2.543 & 2.889 & 2.321 \\
\hline Environmental regulations & 2.091 & 2.429 & 2.000 & 2.182 & 2.179 & 2.184 & 2.409 & 2.471 & 2.370 \\
\hline Other government regulations & 2.188 & 3.143 & $1.920^{*}$ & 2.257 & 2.333 & 2.213 & 2.444 & 2.647 & 2.321 \\
\hline Ability to hire competent management ${ }^{\mathrm{bc}}$ & 2.000 & 3.333 & $1.692 *$ & 2.120 & 2.185 & 2.083 & 2.795 & 2.765 & 2.815 \\
\hline Ability to hire competent hourly employees ${ }^{\text {bc }}$ & 2.485 & 3.143 & 2.308 & 2.654 & 2.571 & 2.700 & 3.400 & 3.667 & 3.222 \\
\hline Balance of power suppliers/vendors ${ }^{\mathrm{b}}$ & 1.720 & - & 1.720 & 1.894 & - & 1.894 & 2.370 & - & 2.370 \\
\hline Balance of power buyers/customers & 2.259 & - & 2.259 & 2.167 & - & 2.167 & 2.385 & - & 2.385 \\
\hline
\end{tabular}

${ }^{\mathrm{z}}$ Data means were based on a 4-point Likert scale, where: $1=$ not important; $2=$ of minor importance; $3=$ important; $4=$ very important. Significance was tested between firm sizes within each firm type and by survey years using analysis of variance and Tukey's honestly significant difference test.

${ }^{\mathrm{y}} \mathrm{LO}$ firms are those indicating they only provide landscape services.

${ }^{x}$ LR firms are those indicating they provide landscape services and retailing.

${ }^{\mathrm{w}}$ LGR firms are those indicating they provide landscape services, wholesale production (growers), and retailing.

'Indicates significance between small and medium firms' total means at 5\%.

'Indicates significance between small and large firms' total means at $5 \%$.

'Indicates significance between medium and large firms' total means at 5\%.

*Indicates significances at the 5\% level between means by survey year (SY2014, SY2019).

using a 4-point Likert scale (where 1 indicated not important and 4 indicated very important) and the percent of firms indicating each factor was important or very important (i.e., selected 3 or 4). Cost of production was the most important factor influencing prices across all firm types and was rated as important by more than $71 \%$ of firms. Other factors influencing prices of landscape businesses included grade of plants, followed by product uniqueness, market demand, other growers' prices, inflation, inventory levels, last year's prices, and other factors. Except for the "other factors" category, LO firms placed more importance in all factors than the other firm types. Comparisons of the percent of firms that viewed the factors as important demonstrated that more LR firms viewed cost of production as important than LO and LGR firms. Overall, the importance of many of the other factors were viewed as less important in 2019 than in 2014, including other growers' prices, grade of plants, market demand, product uniqueness, inventory levels, and last year's prices. Interestingly, cost of production was more important to LO participants in 2019 than 2014, but the opposite was observed for LR firms.

Further comparisons made by firm size using ANOVA and Tukey's HSD at $(P<0.05)$ showed that prices for small firms were more influenced by cost of production (with a mean rating of 3.202) compared with medium firms (mean 2.952; Table 9). Similarly, plant grade had a larger influence on prices of small firms (mean 3.115) compared with large firms (mean 2.855). Product uniqueness had a larger influence on price for small firms (mean 3.041) compared with large firms (mean 2.659), and medium-sized firms (mean 2.902) compared with large firms.
Participants were also asked to rate the importance of 15 factors influencing their ability to remain profitably competitive in the marketplace (i.e., business strategies; Table 10). Weather uncertainty was the top factor influencing business strategies for all types of businesses. Market demand was second in terms of importance across all factors, and it was equally important for all types of businesses. Ability to hire competent hourly employees was the third most important factor. The impact appeared to be slightly greater for undiversified LO firms than LGR operations. Other factors influencing business strategies included labor, own managerial expertise, ability to hire competent management, competition, balance of power buyers/customers, other government regulations, environmental regulations, land, water supply, balance of power supplier/vendors, equity capital, and debt capital. The percent of firms that rated these factors as important was also estimated. Interestingly, when considering the portion of respondents who rated labor factors (i.e., labor, own managerial expertise, ability to hire competent management and hourly employees), a larger portion of LO firms rated labor as important relative to LR and LGR firms. Firm size also influenced the importance of the labor-related factors (i.e., labor, ability to hire competent management, and ability to hire competent hourly employees) for landscaping firms (Table 11). The larger the firm in the total sample and LO groups, the more important the labor factor became relative to small- and medium-sized firms. Large LGR and LR firms also exhibited heightened importance for labor when compared with smaller firms within those categories. The ability to hire competent managers and hourly employees were also more important for larger firms regardless of business type.

A final important aspect is how survey participants reported the importance of factors that influenced the firm's geographic sales range (Table 12). Transportation and plant offerings topped the list, with average ratings of 2.846 $(56.9 \%)$ and $2.822(56.2 \%)$ of the sample, respectively, but showed no difference by firm type. However, survey year did influence the importance of these factors, with both exhibiting higher importance in the 2014 survey than in the 2019 survey. The plant offerings survey year effect was primarily driven by LO and LGR firms. Personnel was the third most important factor (having a rating of 2.798), with a greater effect on the undiversified LO firm compared with LGR firms. The percent of LO firms indicating that personnel was important $(62 \%)$ was also significantly more than the LGR (46\%) and LR firms (47\%). Personnel will likely impact the number of landscape crews a business can operate and therefore the geographic range. Production was fourth in importance (rating of 2.699), with LO and LR firms rating it higher (2.794 and 2.822) than LGR firms (2.449). However, the LO and LR ratings were not significantly different. The percent of LO firms rating production as important $(56 \%)$ was significantly higher than LGR firms (41\%). Marketing was next in importance (2.291), but more so for LR firms and less so for the LGR firms. Equity and debt capital were least important. Both were more important to LO firms when compared with LGR operations. Firm size impacted the importance of the personnel factor (Table 13). Specifically, larger firms rated personnel as more important than small- or medium-sized firms. Large LO firms also rated personnel higher than small 


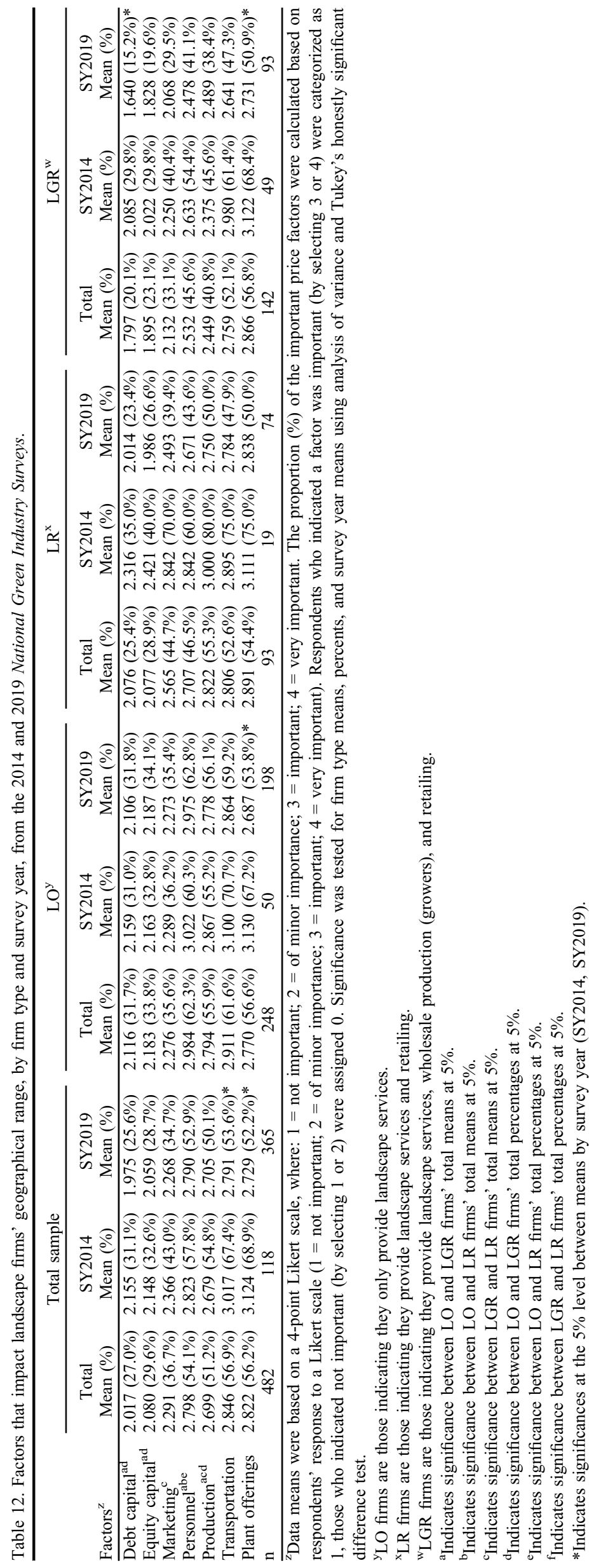

LO firms, while LGR large firms rated personnel higher than medium-sized firms in the LGR category.

\section{Conclusion}

Compared with Torres et al. (2017), this study indicates that little to no change in diversification across the industry has appeared to have occurred in the past five years. Landscape firms predominantly use in-person and telephone sales methods to reach their consumers. Interestingly, this study showed that telephone and other sales methods increased for firms offering only landscape services. Landscape and retailing firms spent the largest portion of their advertising budget on websites, other media, newspapers, radio/TV, and social media. These results suggest that firms who sell to end consumers spend more on these advertising methods to reach a broader group of potential customers. The distribution of the advertising budget spent on different promotion avenues was fairly consistent with Torres et al. (2017), but the landscape only firms seemed to be spending less on advertising. Advertising budgets varied by firm type, with websites and other media capturing the largest budget portion. Landscape businesses diversifying into wholesaling and retailer (LGR) cast a wider net, using traditional multimedia channels to communicate with their end consumers, more so than service only (LO) or retailing firms (LR). Wholesalers focused on industry specific media (for example trade journals and catalogs). Each of these strategies align with firms having different customer groups.

Results demonstrate a consolidation of product offerings for LR operations, while LO firms had the largest amount of different product offerings. While prior studies have not addressed product diversity in the landscaping industry, we expect that many landscape service providers carry a wide variety of products to meet their customers' needs for a full landscape installation. Conversely, wholesalers tend to provide fewer product types but in larger quantities, primarily selling and planting the products they grow.

Sales and marketing methods varied by firm type. In general, in-person and telephone sales represented a larger portion than other sales method options. This is not surprising, given that the use of in-person or telephone sales allows for a more in-depth, two-way conversation that facilitates a better understanding of the situation and how to best meet the customer's needs. Often landscape service firms need to adapt and sell to the customer using information about the site and customer needs.

The higher importance placed on inflation, grade of plant, market demand, and last year's prices of LO firms indicate the competitive nature of this sector of the green industry. Firms dependent on landscaping only must differentiate themselves from other firms with high-quality plants and must stay relevant and competitive because customers are more likely to seek bids from multiple firms on landscaping jobs. One way to stay relevant and competitive is by using online marketing strategies such as social media, websites, and 
Table 13. Factors that impact landscape firms' geographical range, by firm type, size, and survey year, from the 2014 and 2019 National Green Industry Surveys.

\begin{tabular}{|c|c|c|c|c|c|c|c|c|c|}
\hline \multirow[b]{3}{*}{ Factors $^{\mathrm{z}}$} & \multicolumn{9}{|c|}{ Total sample } \\
\hline & \multicolumn{3}{|c|}{ Small } & \multicolumn{3}{|c|}{ Medium } & \multicolumn{3}{|c|}{ Large } \\
\hline & $\begin{array}{l}\text { Total } \\
\text { Mean }\end{array}$ & $\begin{array}{l}\text { SY2014 } \\
\text { Mean }\end{array}$ & $\begin{array}{l}\text { SY2019 } \\
\text { Mean }\end{array}$ & $\begin{array}{l}\text { Total } \\
\text { Mean }\end{array}$ & $\begin{array}{l}\text { SY2014 } \\
\text { Mean }\end{array}$ & $\begin{array}{l}\text { SY2019 } \\
\text { Mean }\end{array}$ & $\begin{array}{l}\text { Total } \\
\text { Mean }\end{array}$ & $\begin{array}{l}\text { SY2014 } \\
\text { Mean }\end{array}$ & $\begin{array}{l}\text { SY2019 } \\
\text { Mean }\end{array}$ \\
\hline Debt capital & 1.950 & 2.200 & 1.901 & 1.979 & 2.161 & 1.903 & 2.115 & 2.118 & 2.115 \\
\hline Equity capital & 2.017 & 2.263 & 1.970 & 2.037 & 2.109 & 2.007 & 2.179 & 2.147 & 2.189 \\
\hline Marketing & 2.350 & 2.550 & 2.310 & 2.198 & 2.263 & 2.170 & 2.361 & 2.429 & 2.342 \\
\hline Personnel $^{\mathrm{bc}}$ & 2.571 & 2.684 & 2.550 & 2.687 & 2.780 & 2.647 & 3.108 & 2.971 & 3.146 \\
\hline Plant offerings & 2.902 & 3.286 & 2.824 & 2.878 & 3.155 & $2.763 *$ & 2.690 & 2.971 & 2.613 \\
\hline \multirow[t]{4}{*}{$\mathrm{n}$} & 123 & 20 & 102 & 200 & 62 & 139 & 160 & 35 & 125 \\
\hline & \multicolumn{9}{|c|}{$\mathrm{LO}^{\mathrm{y}}$} \\
\hline & \multicolumn{3}{|c|}{ Small } & \multicolumn{3}{|c|}{ Medium } & \multicolumn{3}{|c|}{ Large } \\
\hline & Total & SY2014 & SY2019 & Total & SY2014 & SY2019 & Total & SY2014 & SY2019 \\
\hline Personnel $^{\mathrm{b}}$ & 2.647 & 2.667 & 2.644 & 2.990 & 3.200 & 2.915 & 3.263 & 2.909 & 3.319 \\
\hline Production & 2.571 & 3.000 & 2.500 & 2.871 & 2.917 & 2.855 & 2.900 & 2.636 & 2.942 \\
\hline Transportation & 3.014 & 3.182 & 2.983 & 2.929 & 3.107 & 2.859 & 2.797 & 3.000 & 2.765 \\
\hline Plant offerings & 2.957 & 3.200 & 2.915 & 2.811 & 3.320 & $2.629^{*}$ & 2.563 & 2.636 & 2.551 \\
\hline \multirow[t]{4}{*}{$\mathrm{n}$} & 70 & 11 & 60 & 99 & 28 & 71 & 80 & 11 & 69 \\
\hline & \multicolumn{9}{|c|}{$\mathrm{LR}^{\mathrm{x}}$} \\
\hline & \multicolumn{3}{|c|}{ Small } & \multicolumn{3}{|c|}{ Medium } & \multicolumn{3}{|c|}{ Large } \\
\hline & Total & SY2014 & SY2019 & Total & SY2014 & SY2019 & Total & SY2014 & SY2019 \\
\hline Factors ${ }^{z}$ & Mean & Mean & Mean & Mean & Mean & Mean & Mean & Mean & Mean \\
\hline Debt capital & 1.952 & 2.250 & 1.882 & 2.250 & 2.714 & 2.120 & 2.000 & 2.000 & 2.000 \\
\hline Equity capital & 1.950 & 2.250 & 1.875 & 2.094 & 2.571 & 1.960 & 2.128 & 2.375 & 2.065 \\
\hline Marketing & 2.476 & 2.500 & 2.471 & 2.719 & 3.286 & 2.560 & 2.487 & 2.625 & 2.452 \\
\hline Factors $^{\mathrm{z}}$ & Mean & Mean & Mean & Mean & Mean & Mean & Mean & Mean & Mean \\
\hline Debt capital & 1.750 & 2.000 & 1.680 & 1.703 & 1.880 & 1.590 & 2.000 & 2.467 & 1.682 \\
\hline Equity capital & 1.806 & 2.000 & 1.760 & 1.800 & 1.840 & 1.775 & 2.135 & 2.333 & 2.000 \\
\hline Marketing & 2.406 & 2.667 & 2.346 & 1.985 & 2.077 & 1.925 & 2.158 & 2.375 & 2.000 \\
\hline Personnel & 2.452 & 2.333 & 2.480 & 2.333 & 2.481 & 2.238 & 2.949 & 3.000 & 2.913 \\
\hline Production & 2.313 & 2.167 & 2.346 & 2.478 & 2.385 & 2.537 & 2.513 & 2.438 & 2.565 \\
\hline Transportation & 2.452 & 2.833 & 2.360 & 2.826 & 3.000 & 2.714 & 2.878 & 3.000 & 2.800 \\
\hline Plant offerings & 2.909 & 3.714 & $2.692 *$ & 2.857 & 3.000 & 2.773 & 2.846 & 3.063 & 2.696 \\
\hline $\mathrm{n}$ & 33 & 7 & 26 & 70 & 27 & 47 & 41 & 16 & 25 \\
\hline
\end{tabular}

${ }^{\mathrm{z}}$ Data means were based on a 4-point Likert scale, where: 1 = not important; 2 = of minor importance; $3=$ important; $4=$ very important. Significance was tested between firm sizes within each firm type and survey years using analysis of variance and Tukey's honestly significant difference test.

${ }^{\mathrm{y}} \mathrm{LO}$ firms are those indicating they only provide landscape services.

${ }^{x}$ LR firms are those indicating they provide landscape services and retailing.

${ }^{\mathrm{w}}$ LGR firms are those indicating they provide landscape services, wholesale production (growers), and retailing.

andicates significance between small and medium firms' total means at $5 \%$.

'Indicates significance between small and large firms' total means at 5\%.

'Indicates significance between medium and large firms' total means at $5 \%$.

*Indicates significances at the 5\% level between means by survey year (SY2014, SY2019).

e-mail advertising. Weather uncertainty was important for all analyzed businesses, but more important for LR firms and those firms focused only on landscaping (LO), than for LGR firms. Landscape installation and maintenance are dependent on appropriate weather, and retail sales are usually impacted by weather that makes shopping pleasant.
Interestingly, labor was an important factor that impacted business practices and geographical expansion for landscape firms. For LO and LGR operations, labor was an important factor impacting their business practices and geographical expansion. As a service business, firms that primarily participate in landscaping are selling their labor, so labor is most critical for those firms. Labor is an expensive component to many firms; and landscaping work can be physically demanding, which may limit the labor pool. Strategies addressing labor shortages and training may be a means to support landscaping firms and their future business needs. 
Landscape service firms provide a variety of services and often diversify to include different business elements such as wholesale or retail operations. Given the diversity within this green industry sector, few studies have addressed the marketing and business practices used within the industry. This research used data from industry surveys conducted in 2014 and 2019 to identify key landscape service firms' marketing and business practices and how those practices vary by business type and size. Overall, landscape firms demonstrated wide diversity in product offerings, marketing communications, and other factors impacting business strategies. Given the diversity and lack of research in the landscape service industry, there are ample opportunities for future studies to delve into each of the topics discussed in this article. This study highlighted key factors affecting landscape service businesses and marketing practices used in the industry. Further research in each of these categories could aid landscape firms with future business decisions.

\section{Literature Cited}

Behe, B.K., J.H. Dennis, C.R. Hall, A.W. Hodges, and R.G. Brumfield. 2008. Regional marketing practices in U.S. nursery production. HortScience 43(7):2070-2075, doi: 10.21273/HORTSCI.43.7. 2070.

Brooker, J.R. and S.C. Turner. 1990. Trade flows and marketing practices within the United States nursery industry. Southern Coop. Ser. Bul. 358 for Southern Reg. Res Project S-103. Univ. of Tennessee Agr. Expt. Sta. 1 Aug. 2017. $<$ http://aggie-horticulture.tamu.edu/faculty/hall/ publications/SCSB358.pdf $>$.

Brooker, J.R., R.A. Hinson, and S.C. Turner. 2000. Trade flows and marketing practices within the United States nursery industry: 1998. Southern Coop. Ser. Bul. 397 for Southern Reg. Res Project S-290. Univ. of Tennessee Agr. Expt. Sta. 1 Aug. 2017. <http://aggie-horticulture.tamu. edu/faculty/hall/publications/SCB397.pdf > .
Brooker, J., D. Eastwood, C. Hall, K. Morris, A Hodges, and J. Haydu. 2005. Trade flows and marketing practices within the United States nursery industry: 2003. Southern Coop. Ser. Bul. 404. Univ. of Tennessee Agr. Expt. Sta. 1 Aug. 2017. <http://aggie-horticulture.tamu.edu/ faculty/hall/publications/SCB404.pdf $>$.

Campbell, B.L. and C.R. Hall. 2010. Effects of pricing influences and selling characteristics on plant sales in the green industry. HortScience 45:575-582, doi: 10.21273/HORTSCI.45.4.575.

Cole, H.S., T. DeNardin, and K.E. Clow. 2017. Small service businesses: Advertising attitudes and the use of digital and social media marketing. Serv. Mark. Q. 28(4):203-212, doi: 10.1080/ 15332969.2017.1394026.

Dillman, D.A. 2000. Mail and internet surveys: The tailored design method. Vol. 2. Wiley, New York, NY.

Diment, D. 2020. Landscaping services in the U.S. IBISWorld Report \#56173.

Eid, R. and El-Gohary, H. 2013. The impact of emarketing use on small business enterprises' marketing success. The Service Industries J. 33(1): 31-50, doi: 10.1080/02642069.211.594878.

Florkowski, W.J. and G. Landry. 2000. An economic profile of the professional turfgrass and landscape industry. Res. Report No. 672, Georgia Agr. Expt. Sta. 29 Aug. 2017. <https://www.researchgate. net/profile/Wojciech_Florkowski/publication/ 266454071_An_Economic_Profile_of_the_ Professional_Turfgrass_and_Landscape_Industry_ in/links/54a6fl f80cf267bdb90a0704.pdf >.

Garber, M.P. and K. Bondari. 1992a. Landscape architects as related to the landscape/nursery industry: I. Impact on demand for plant material. J. Environ. Hort. 10:69-72, doi: 10.24266/07382898-10.2.69.

Garber, M.P. and K. Bondari. 1992b. Landscape architects as related to the landscape/nursery industry: II. Selection of the production nursery and plant availability. J. Environ. Hort. 10:73-77, doi: 10.24266/0738-2898-10.2.73.

Garber, M.P. and K. Bondari. 1992c. Landscape architects as related to the landscape/nursery industry: III. Sources of plant material information. J. Environ. Hort. 10:78-80, doi: 10.24266/0738-2898-10.2.78.

Hall, C.R., A.W. Hodges, H. Khachatryan, and M.A. Palma. 2020. Economic contributions of the green industry in the United States in 2018 . J. Environ. Hort. 38(3):73-79, doi: 10.24266/ 0738-2898-38.3.73.

Haynes, C., A.M. VanDerZanden, and J.K. Iles. 2007. A survey of the ornamental horticulture industry in Iowa. HortTechnology 17:513-517, doi: 10.21273/HORTTECH.17.4.513.

Hodges, A.W., C.R. Hall, and M.A. Palma. 2010. Trade flows and marketing practices within the U.S. Nursery Industry, 2008. Southern Coop. Ser. Bul. 411, Multistate Reg. Res Project S-1021. 1 Aug. 2017. <http://aggie-horticulture.tamu.edu/ faculty/hall/publications/SCSB411.pdf >.

Hodges, A.W., H. Khachatryan, C.R. Hall, and M.A. Palma. 2015a. Production and marketing practices and trade flows in the United States green industry, 2013. Southern Coop. Ser. Bul. 420, Univ. of Florida Agr. Expt. Sta. 1 Aug. 2017. $<$ http://saaesd.ncsu.edu/docs/National\%20Green $\% 20$ Industry $\% 20$ Survey $\% 20$ report $\% 202014 \%$ 20SCSB \%2052615.pdf $>$.

Hodges, A.W., C.R. Hall, M.A. Palma, and H. Khachatryan. 2015b. Economic contributions of the green industry in the United States in 2013. HortTechnology 25:805-814, doi: 10.21273/ HORTTECH.25.6.805.

Khachatryan, H., A. Hodges, C. Hall, and M. Palma. 2020. Production and marketing practices and trade flows in the United States green industry, 2018. Southern Cooperative Bul. Series \#421, ISBN: 1-58161-421-9.

Li, Y., M.A. Palma, C.R. Hall, H. Khachatryan, and O. Capps, Jr. 2019. Measuring the effects of advertising on green industry sales: A generalized propensity score approach. Appl. Econ. 51(12):1303-1318, doi: 10.1080/00036846.2018. 1527448.

Palma, M.A., C.R. Hall, B. Campbell, H. Khachatryan, B. Behe, and S. Barton. 2012. Measuring the effects of firm promotion expenditures on green industry sales. J. Environ. Hort. 30(2):83-88, doi: 10.24266/0738-2898.30.2.83.

Lawn and Landscape. 2016. State of the industry report. 30 Aug. 2017. <http://www.lawnandland scape.com/fileuploads/file/2016/11/SOI_PDF_ 2016.pdf $>$.

Torres, A., S.S. Barton, and B.K. Behe. 2017 Business and marketing practices of U.S. landscape firms. HortTechnology 27(6):884-892, doi: 10.21273/HORTTECH03835-17. 